\title{
AN ANALYSIS OF USING NUMBERED HEAD TOGETHER LEARNING MODEL IN GEOGRAPHY SUBJECT AT CLASS X IPS 5 CLASS IN SMAN 1 LUHAK NAN DUO
}

\author{
*Muhammad Hakim ${ }^{1}$, Lusi Hervina ${ }^{2}$, and Khairani $^{3}$ \\ ${ }^{1}$ Student of Geography Education Magister Program, Padang State University \\ ${ }^{2}$ Student of Indonesian language Education Magister Program, Bung Hatta University \\ ${ }^{3}$ Faculty of Social Science, Padang State University \\ Email: lord.hqeem@gmail.com
}

*Corresponding Author, Received: March 11, 2020, Revised: May 17, 2020, Accepted: June 11, 2020

\begin{abstract}
The aims of this research were to reveal the data, information and discuss the using of Numbered Head Together Learning Model of Geography at X IPS 5 Class in SMAN 1 Luhak Nan Duo. The type of the research was a descriptive research with a quantitative approach. This research was conducted at SMAN 1 Luhak Nan Duo through the subject of this research being students at Class X IPS 5, amounting to 33 students. Data collection was done through observation sheets, questionnaires, and documentation. The data technique analysis was the quantitative descriptive by the calculation of the percentage and total respondents' achievements. The conclusion of this research was the students' response to the application of the learning model of the Numbered Head Together at X IPS 5 Class of SMAN 1 Luhak Nan Duo was in the much-needed category and was in the very good category.
\end{abstract}

Keywords: Number Head Together, Learning, Geography

\section{INTRODUCTION}

Quality of education is the main factor that is important for the development of the younger generation as the nation's successors. Education need of every citizen who always longs to improve the quality of human resources as a key element in the country's development. Improving the quality of education is an expected the goal in the development of National Education in Indonesia. This is in accordance with Law No. 20 of 2003 concerning National Education System article 3: "National education has a function to develop the capabilities and form the character and civilization of a dignified nation in order to educate the life of the nation, aiming at developing the potential of learners to become human beings who believe and fear 
http://ijeds.ppj.unp.ac.id/index.php/IJEDS

God Almighty, noble, healthy, knowledgeable, capable, creative, independent, and become citizens who are democratic and responsible (Milawati, 2011).

One of the subjects taught is Geography (Hermon, 2015). The subjects taught at each level of education have their weights respective. The government regulation of education and culture No. 69 of 2013 concerning the Basic Framework and Structure of high school Curriculum explains that the meaning of Geography is the study of relationships of various phenomena and events that occur on earth, both physical and related to living things and their problems through spatial, ecological, and regional. The results of the geography study are directed to the interests of the program, the process and the success of the development. The process of describing, understanding, identifying, evaluating, and solving development problems, geography is assisted by a number of technologies such as remote sensing, maps, and Geographic Information Systems (GIS) (Hermon, 2015).

The aims of Geography subjects according 2013 curriculum, students to have the ability to: 1) Understand spatial, environmental and territorial patterns and processes related to geosphere phenomena in national and global contexts. 2) Mastering basic skills in obtaining data and information, applying geographic knowledge in daily life, and communicating it for the benefit of the progress of the Indonesian people. 3) Showing the caring behavior towards the environment and using natural resources wisely and having tolerance towards the diversity of the nation's culture. 4) Showing the love for the homeland, being proud as the Indonesian nation, and being responsible for the integrity of the Unitary State of the Republic of Indonesia based on Pancasila and the 1945 Constitution.

The most important task of educators in learning can support better behavior change for students through the condition the learning environment. In achieving this goals, educators can use a variety of learning resources to support the process of behavior change in students. Besides, educators must also use strategies or learning models to make students are interested in and easily understand the material to be taught. An appropriate learning models in the selection and use by the teacher will help students easily be able to understand the material presented by the teacher and can help achieve the learning objectives that have been planned. The use of learning models is one important part of the process of teaching and learning activities, the success of students in understanding the material delivered by the teacher depends on the learning model used by the teacher. 
http://ijeds.ppj.unp.ac.id/index.php/IJEDS

Learning model currently widely used by students is the cooperative learning model. The cooperative learning defined as a working system or structured group learning (Hermon, 2006). In this learning system students are required to collaborate, to get the maximum results from what is taught by the teacher. In addition to being able to give students the freedom to be creative, this model also emphasizes the activeness of students in the classroom, while the teacher is only a facilitator. The essence of cooperative learning is the responsibility of individuals as well as groups, so that students are develop positive interdependence attitudes which in the end the learning that run optimally (Shoimin, 2014).

Cooperative learning model is a learning model with a grouping / small team system. Small team members consist of four to six people. This strategy is concern and recommended by education experts for use (Sidiq, 2008). Number Head Together (NHT) is one type of cooperative learning model can makes students actively learn in groups. NHT learning model was first developed by Spencer Kagan in 1992, involving many students in reviewing the material covered in a lesson and checking their understanding of the content of the lesson, this type is also used to reinforce concepts before they are carried out the test. The structure developed requires that students work together, help each other in small groups cooperatively. There are structures that have the aim of increasing academic mastery and there are structures teaching social skills (Wul and Pan, 2013).

NHT models allow students to share their ideas and consider the most appropriate answers. Based on these answers, the students can develop a deeper discussion so that students can find answers to questions or assignments that given by the teacher as intact knowledge (Yildirin, 2012). The strengths of the NHT are as follows: 1) Providing opportunities for students to share ideas and consider the most appropriate answers, 2) Increase students' enthusiasm for cooperation, 3) Can be used to all subjects and grade levels (Hermon, 2006).

The NHT are use four-phase structure as follows:

\section{Phase 1: Numbering}

In this phase, the teacher divides students into groups of 4-6 people. Each group member is given a number between one to five. 
http://ijeds.ppj.unp.ac.id/index.php/IJEDS

2. Phase 2: Asking questions

In this phase, the teacher presents a question to students in the form of question sentences and specific. For example, "Make sure everyone knows the 5 provincial capitals located on the island of Sumatra".

3. Phase 3: Think Together

In the third phase, students express their opinions on the answers to these questions and convince each member in their team to know the team's answers.

4. Phase 4: Answer

In the fourth phase, the teacher calls a certain number, then the student whose number is appropriate raises his hand and tries to answer the question for the whole class (Yildirin, 2012).

Based on the results of the researchers' initial interviews with the Geography teacher in SMAN 1 Luhak Nan Duo, it is known that Geography learning has now shifted from teachercentered learning or commonly referred to as teacher-centered to learning that applies cooperative learning models, one of which is Numbered Head Together. Based on information from a geography study in SMAN 1 Luhak Nan Duo has several times applied the cooperative learning model of the Group Investigation type, Jigsaw, the Articulation type, and the Numbered Head Together type. However, many types of cooperative learning most often apply the Numbered Head Together type specifically at Class X students at SMAN 1 Luhak Nan Duo.

Based on the experience gained in the previous school year, the problem that is often encountered when teachers apply cooperative learning models is that the teacher only frees students to discuss looking for answers to the given problems, students who are most active in groups are smart students or students who sit on the front bench so that less smart students rather lag. So that the most visible high learning outcomes are smart students. Besides, when students hold group discussions the teacher is not supervising or guiding the course of the discussion, so students who are less intelligent in the group feel somewhat relaxed because there is no supervision from the teacher. Based on the problem above, the researcher is interested in doing descriptive research to reveal data, information and discussion about the analysis of the use of the Numbered Head Together Learning Model in Geography Learning in Class X IPS 5 of SMAN 1 Luhak Nan Duo. 


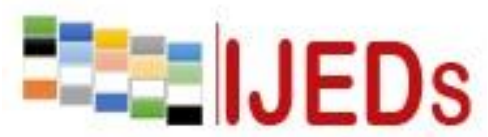

http://ijeds.ppj.unp.ac.id/index.php/IJEDS
International Journal of Educational Dynamics

Vol. 2 No. 2 (pp. 1-9) June 2020

p_ISSN 2655-4852

e_ISSN 2655-5093

(a)

\section{METHOD}

This research uses a descriptive analysis method with a quantitative approach through the aim to reveal the data, information and discuss the analysis of the use of the Numbered Head Together Learning Model in Geography subject at X IPS 5 Class in SMAN 1 Luhak Nan Duo. Descriptive research is a form of research that aimed to describing existing phenomena, both natural phenomena and man-made phenomena. Phenomena can be in the form of forms, activities, characteristics, changes, relationships, similarities, and differences between one phenomenon with another phenomenon (Yildirin, 2012). Descriptive research has the following characteristics: 1 . Relating to conditions that occur at the time, 2 . Outlining only one variable or several variables but outlined one by one, 3. The variables studied were not manipulated or there was no treatment (Hermon and Dalim, 2006; Gupta and Ahuja, 2014; Gures, 2016). This research was conducted in SMAN 1 Luhak Nan Duo with the subject being students at X IPS 5 Class, amounting to 33 students. Data collection is done through observation sheets, questionnaires and documentation. The technique used in analyzing the data collected is quantitative descriptive calculation of the total achievements of respondents.

\section{RESULTS AND DISCUSSION}

Secondary Education Curriculum Structure, consisting of Compulsory Subjects and Elective Subjects explains that the contents of the curriculum and the substance packaging for compulsory subjects for between Senior High Schools and Vocational High Schools are the same. While Geography for Senior High Schools levels is determined to be part of the Specialization Subject Group which aims to provide opportunities for students to develop their interests in a group of subjects following their scientific interests in higher education and develop their interest in a particular discipline or skill. This proves that the importance of learning Geography for the future of students.

SMAN 1 Luhak Nan Duo is one of the best high schools with accreditation A, located on Jl. Lintas Simpang Empat-Maggopoh Km.08 Sariak, West Pasaman Regency, Riau Province. Luhak Nan Duo High School 1 consists of 836 students and 67 teachers integrated into 3 majors with 102 lessons, one of which is Geography learning. Learning geography in this school is one of the best in SMAN 1 Luhak Nan Duo, it is marked by the achievements of the students. Learning geography in Class $\mathrm{X}$ consists of several materials including basic 
http://ijeds.ppj.unp.ac.id/index.php/IJEDS

knowledge of geography, basic knowledge of mapping, remote sensing, and geographic information systems, geographic research steps, planetary dynamics, lithosphere dynamics, atmospheric dynamics, hydrosphere dynamics.

Learning geography in SMAN 1 Luhak Nan Duo especially at X Class reached a positive trend where this is inseparable from the role of the teacher who is very creative in applying learning models that are fun and centered on students. Geography Learning tends to apply the cooperative learning model, this is because the cooperative model is very effective in overcoming problems in learning. One model of cooperative learning that is often applied in SMAN 1 Luhak Nan Duo is Numbered Head Together (NHT). This model designed to influence student interaction patterns and as an alternative to traditional classroom structure resources. Starting with the numbering, each group member are responsible for the group's work, so there is no separation between one student and other students in one group.

Based on observations doing by researchers at X IPS 5 class is one of the classes in Geography learning that is consistent in applying the Numbered Head Together learning model. This model is very effective to increase the activeness and students understanding in learning materials to be maximal. That is because of the activeness of students when following the learning material, both in asking questions and having very good opinions. The activeness of these students in Geography learning has an impact on students' high understanding of the material and student learning outcomes. Thus what is the goal of these subjects will be easily achieved. From the results of daily tests at X IPS 5 class in Geography learning, the percentage of students who reach mastery is above $85 \%$. This indicates that the model has been implemented well.

The steps of the Numbered Head Together learning model implemented in this class according to the following opinion: 1) Students are divided into groups. Each student in each group gets a number. 2) The teacher gives an assignment and each group does it. 3) The group discusses the correct answer and makes sure each group member can do it / know the answer well. 4) The teacher calls one of the numbers called out of the group to report or explain the results of their cooperation. 5) Response with other friends, then show another number. 6) Conclusions (Hermon and Dalim, 2005; AlKialbi, 2015; Amini, 2015).

At this stage an analysis of the need to use this model at X IPS 5 class in SMAN 1 Luhak Nan Duo. The aims of this analysis to determine the importance of the Numbered Head 
http://ijeds.ppj.unp.ac.id/index.php/IJEDS

Together learning model at X IPS 5 class in SMAN 1 Luhak Nan Duo in improving student learning outcomes in a better direction. The data was obtained through a questionnaire distributed to 33 students at the X IPS 5 class in SMAN 1 Luhak Nan Duo. Based on the questionnaire, obtained data about the needs analysis of the importance of learning models at X IPS 5 class in SMAN 1 Luhak Nan Duo, for more details, it can be seen from the following table:

Table 1 Distribution of Needs Analysis Frequency

\begin{tabular}{|c|l|c|c|}
\hline No & Requirement Analysis & Frequency & Percentage \\
\hline 1 & Very Needed & 20 & 60 \\
\hline 2 & Needed & 8 & 24 \\
\hline 3 & Needed Enough & 5 & 16 \\
\hline 4 & Less Needed & 0 & 0 \\
\hline 5 & Not Needed & 0 & 0 \\
\hline & & 33 & 100 \\
\hline
\end{tabular}

Based on the table distribution of the needs analysis frequency above, it is known that the category that very needed gets a $60 \%$, the category needed gets a $24 \%$, the category needed enough gets $16 \%$, the category less needed and not needed gets $0 \%$. Based on these results, it was concluded that students' responses to the application of the learning model of the Numbered Head Together learning model were in the category of very much needed.

The next step was an analysis of the use of the Number Head Together learning model X IPS 5 class in SMAN 1 Luhak Nan Duo. The aims of this analysis to determine the criteria for using the model all this time. The data was obtained through a questionnaire distributed to 33 students of Class X IPS 5 of SMAN 1 Luhak Nan Duo. Based on the questionnaire, obtained data about the analysis of the criteria for the use of learning models type Numbered Head Together at X IPS 5 class in SMAN 1 Luhak Nan Duo so far, for more details can be seen from the following table:

Table 2. Frequency Distribution of NHT Model Use

\begin{tabular}{|l|l|c|c|}
\hline No & Analysis & Frequency & Percentage \\
\hline 1 & Excellent & 25 & 76 \\
\hline 2 & Good & 6 & 18 \\
\hline 3 & Good Enough & 2 & 6 \\
\hline 4 & Less & 0 & 0 \\
\hline 5 & Not Good & 0 & 0 \\
\hline & \multicolumn{2}{|c}{} \\
\hline
\end{tabular}


http://ijeds.ppj.unp.ac.id/index.php/IJEDS

Based on the distribution table of the frequency distribution analysis of the use of the NHT model above, it is known that the excellent category gets $76 \%$, the good category $18 \%$, good enough category gets $6 \%$, the less and not good category gets $0 \%$. Based on these results, it was concluded that the criteria for using this model had been in the very good category. From these results, it is known that the application of the Numbered Head Together learning model at X IPS 5 class in SMAN 1 Luhak Nan Duo is following the steps of the NHT model. Based on the results of the research above, it can be seen that it is very necessary to use a good Numbered Head Together learning model and following the steps in Geography. It cause by the application of the NHT model in learning Geography gives positive results to students, where this model is fun and makes students active. This is in line with the theory according to Jamal where Numbered Head Together provides opportunities for students to share ideas and consider the most appropriate answers. Based on these answers, students can develop more indepth discussion to find an answers of questions or assignments given by the teacher as intact knowledge (Abas, 2006; Ahmad, 2012; Abdulrahman Al-Shamrani and Dimitorv, 2017; Abidin, 2017). This then has a positive impact on students.

\section{CONCLUSION}

Teaching materials for reading comprehension by using the Somatic Auditory Visual and Intellectual (SAVI) Model in fourth grade students of elementary school meet valid, practical, and effective criteria. Valid criteria are reflected from the results of validation which is assessed by the expert. Practical criteria that are reflected in the learning process carried out through observation sheets of student activities. Meanwhile, the effective criteria is reflected by being able to improve the reading comprehension ability of fourth grade students in elementary school.

\section{REFERENCES}

Abas, S. 2006. Effective Indonesian Language Learning in Elementary School. Jakarta: Ministry of National Education Directorate General of Education.

Abdulrahman Al-Shamrani and Dimiter M. Dimitorv. 2017. Cognitive Diagnostic Analysis of Reading Comprehension Items: The Case of English Proficiency Assessment in Saudi Arabia. International Journal Of School And Cognitive Psycholigi, 196.

Abidin, Y. 2017. Language Learning Based on Character Education. Bandung: Refika Aditama. Ahmad, Z. A. 2012. Learning Planning and Design Until Implementation. Yogyakarta: Diamond Library. 
http://ijeds.ppj.unp.ac.id/index.php/IJEDS

AlKialbi, A. S. 2015. The Place of Reading Comprehension in Second Language Acquisition. Journal of Literature, Languages and Linguistics, 14.

Amini, R. 2015. Development of Elementary School Learning Concepts of Elementary Science Using the SAVI Approach. pedagogy, 35.

Gupta, M and Ahuja, J. 2014 Cooperative Integrated Reading Composition (Circ): Impact On Reading Comprehension Achievement In English Among Seventh Graders. International Journal of Research in Humanities, Arts and Literature (IMPACT: IJRHAL) ISSN (E): 2321-8878; ISSN (P): 2347-4564 Vol. 2.

Gures, O. M. 2016 Investigating Reading Comprehension and Learning Styles In Relation To Reading Reading Strategies In L2 In A Foreign Language. Volume 28, No. 1 PP.2042.

Hermon, D and Y. Dalim. 2005. Penggunaan Media Audio Visual untuk Meningkatkan Kreatifitas Belajar. Jurnal Pembelajaran. 28 (3) 266-276

Hermon, D and Y. Dalim. 2006. Penerapan Kuliah Lapangan untuk Meningkatkan Hasil Belajar Mahasiswa. Forum Pendidikan. 28 (3) 156-161

Hermon, D. 2015. Arahan Kebijakan Keberlanjutan Pendidikan 10 Tahun Pasca Bencana Tsunami di Kabupaten Aceh Jaya Provinsi Aceh. Seminar Nasional Geografi. Master Program of Geography Education. Universitas Negeri Padang

Hermon, D. Geografi Bencana Alam. Jakarta: PT RajaGrafindo Persada. 2015.

Shoimin, A. 2014. 68 Innovative Learning Models in the 2013 Curriculum. Yogyakarta: ArRuzz Media.

Sidiq, M. D. 2008. Development of Teaching Materials. Jakarta: Ministry of National Education.

Wul, Y., and Pan, Y. 2013. The cooperative learning effects of reading comprehension and learning motivation of eFL freshmen. English language Teaching,, Vol. 6, No.5.

Yildirin, A. 2012. Silent Of Oral Reading Fluency. International Journal on New Trends in Education and Their Implication, 79.

Yanti, N., and A. Zuhairi. 2016. Strategies Training In The Teaching Of Reading Comprehension For EFL Learners in Indonesia. English Language Teaching, Vol. 9 No.2.

Zacharias, J. 2017. Local Environment And Social Factor In Primary School Children Afterschool Commute In China. Published By Elsevier Inc, 83. 